\title{
Extracorporeal membrane oxygenation for avian influenza A (H7N9) patient with acute respiratory distress syndrome: a case report and short literature review
}

\author{
Qi Nie, Ding-yu Zhang ${ }^{*}$ (D), Wen-juan Wu, Chao-lin Huang and Zheng-yi Ni
}

\begin{abstract}
Background: Extracorporeal membrane oxygenation (ECMO) is performed as an acceptable life-saving bridging procedure in patients with severe acute respiratory distress syndrome (ARDS).To patients with avian influenza A (H7N9)-associated ARDS, ECMO could be adopted as a feasible therapeutic solution. We present our successful experience with ECMO utilized in a respiratory failure patient with H7N9 infection.

Case presentation: A 44 years-old female with H7N9-induced ARDS was admitted to intensive care unit (ICU) and was treated with veno-venous ECMO for six days, antiviral therapy, prolonged corticosteroid infusion and other therapies. She suffered significant hemorrhage requiring transfusion of platelets and multidrug-resistant Acinetobacter Baumannii infection during ECMO support. Bleeding and infection almost killed the patient's life. Fortunately, she was alive at last and completly recovered after 38 days of ICU stay.

Conclusions: ECMO was effective in this H7N9 patient with a fatal respiratory failure. Mechanical circulatory support was the only chance for our patient with H7N9-associated ARDS to survive until respiratory function recovery. Early detection and rapid response are essential to these serious ECMO-associated complications such as hemorrhage, thrombosis and infection.
\end{abstract}

Keywords: Extracorporeal membrane oxygenation, Avian influenza A H7N9, Acute respiratory distress syndrome

\section{Background}

Acute respiratory distress syndrome (ARDS) is a serious hypoxaemia and progressive dyspnea condition which is caused by various direct or indirect factors leading to the development of acute lung injury. Although medical technology is more and more advanced and modern medicine for ARDS has been further systematic in pathological physiology, diagnosis and treatment scheme, mortality rate due to ARDS is still high [1]. The study found that fatality rate of patients with severe ARDS was as high as 62\% [2]. Extracorporeal membrane oxygenation (ECMO) is a feasible life-saving support therapy for patients with severe ARDS that is refractory to conventional mechanical ventilation (MV) [3]. Originally

\footnotetext{
* Correspondence: 3180001668@qq.com

Wuhan Medical Treatment Center, Yintan Road NO.1, Wuhan 430023, Hu Bei, China
}

(c) The Author(s). 2017 Open Access This article is distributed under the terms of the Creative Commons Attribution 4.0 International License (http://creativecommons.org/licenses/by/4.0/), which permits unrestricted use, distribution, and reproduction in any medium, provided you give appropriate credit to the original author(s) and the source, provide a link to the Creative Commons license, and indicate if changes were made. The Creative Commons Public Domain Dedication waiver (http://creativecommons.org/publicdomain/zero/1.0/) applies to the data made available in this article, unless otherwise stated. patients with good results [4], the use of ECMO has been progressively extended to adult population [5]. Key factors for the indication of ECMO are represented by prognosis of the underlying disease, timing, quality of life of survivors and the possibility of being lung transplant candidate [6]. Main ventilation strategy of ECMO is to allow lungs of patients to rest and maintain theiropening, in order to get opportunity for treatment of lung disease [7].

Occurrence of ARDS in patients with H7N9 infection is associated to an extremely high mortality especially before the introduction of effective antiviral treatment. We present a clinical case of the successful use of ECMO in a patient with H7N9-associated ARDS. 


\section{Case presentation}

The patient who had previously been exposed to poultry was a 44 years-old female that had avian Influenza A(H7N9) infection and presented with ARDS. After 15 days of flu-like respiratory symptoms and fever, the patient developed severe respiratory distress and was admitted to the emergency ward of local hospital. Two days after the beginning of treatment with antibiotic, the patient developed mild ARDS.That was initially treated with non-invasive mechanical ventilation (NIV) in the Intensive Care Unit (ICU) of superior hospital. Later, ARDS evolved to the severe stage [8] and a significant septic shock occurred. For this reason, three days after the onset of respiratory failure, the patient received endotracheal intubation and mechanical ventilation(MV).The patient was referred to ECMO center of our hospital in March 13, 2016 since conventional protective MV did not improve the patient's condition..Severe ARDS ( $\mathrm{PaO} 2 /$ $\mathrm{FiO} 2=46 \mathrm{mmHg}$ ) due to pneumonia caused by avian influenza $A(H 7 N 9)$ virus was diagnosed since the bronchial lavage fluid (BLF) and pharynx swab were positive for H7N9-RNA. Chest X-ray and CT scan showed diffuse and bilateral pulmonary real change opacities (Fig. 1).

Upon arrival at the referral ECMO center, sepsis, septic shock, acidosis and so forth, were treated and veno-venous ECMO (VV-ECMO) was initiated (18 F cannula was inserted into right jugular vein and right femoral vein, respectively). The by-pass was established with a blood flow of $4.13 \mathrm{~L} / \mathrm{min}$ and sweep gas of $4 \mathrm{~L} /$ min. This strategy offered the advantage to rest the lung and minimize the risk of ventilator-induced lung injury [9]. Details of antiviral therapy, steroid therapy, antibiotic,antifungal treatments and so on are shown in Table 1.
With the application of ECMO, the patient's blood gas analysis results gradually improved (Table 2). Chest radiography was taken every day. In the first radiograph (Fig. 1), opacities and consolidation of almost the entire left lung were demonstrated as "white lung". However, the opacities and consolidation disappeared gradually (Fig. 1) when the infection was controlled, and the number of white cells returned to normal too.

Treatment with ECMO was maintained for 6 days and stopped due to severe thrombocytopenia because heparin must be applied when starting ECMO. Subcutaneous hemorrhage occurred in fingers and left thigh of the patient. Bloody liquid was sucked out from bronchi. Platelet antibodies were detected in blood and platelet transfusion was ineffective. Fortunately, platelets gradually returned to normal after the withdrawal of ECMO (Fig. 1). At the same time, multidrug-resistant Acinetobacter Baumannii infection was found in BLF, sputum and blood. It was fortunate that infection and thrombocytopenia were found in time and gradually cured. On April 9, the patient was successfully extubated and ventilated with non-invasive ventilation (NIV) by face-mask. After 11 days, the patient was discharged to a step down ICU and then at home. After more than eight months of follow-up, the pharynx swab H7N9-RNA remained negative and she was alive finally with a good physical condition.

\section{Discussion}

Favorable outcomes in severe ARDS have been reported with ECMO use during the 2009 H1N1 influenza pandemic, which led to increased interest and use of ECMO for refractory respiratory failure. VV-ECMO can supply sufficient pulmonary support when gas exchange is

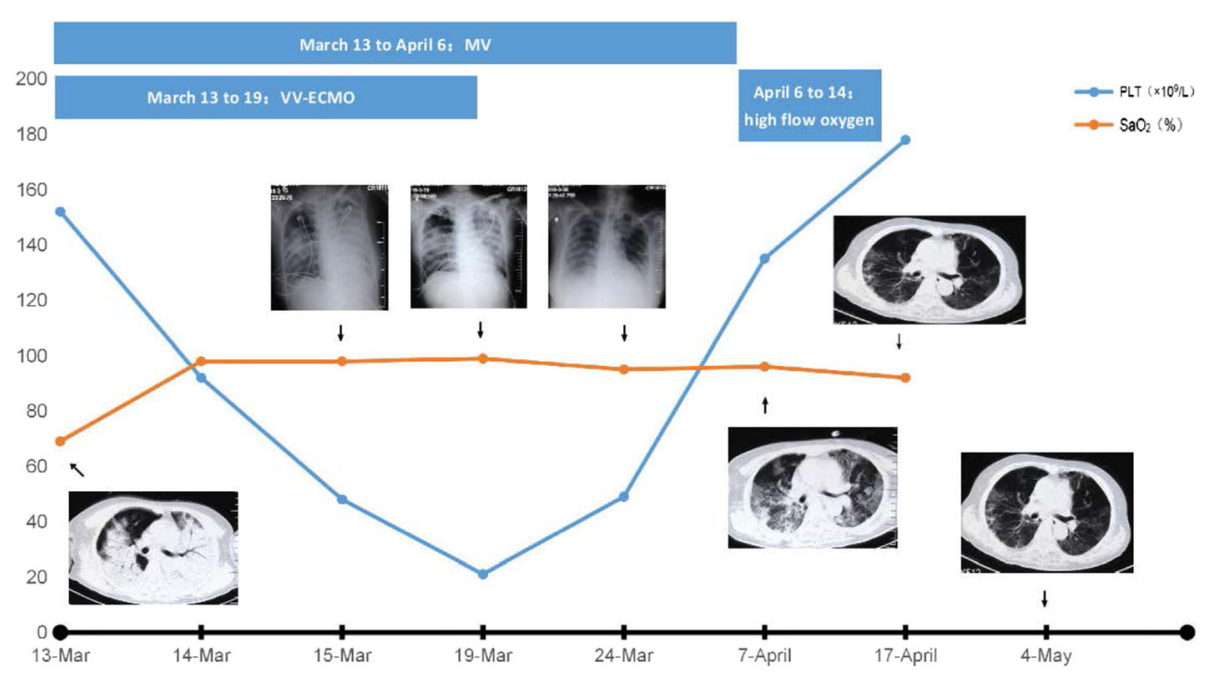

Fig. 1 Chest X-Ray(Bedside)and computer tomography scans(No PEEP). MV mechanical ventilation,W-ECMO veno-venous extracorporeal membrane oxygenation. $\mathrm{SaO}_{2}$ Arterial Oxygen Saturation(\%,NV> 95\%)PLT platelet( $\left.\times 10^{9} / \mathrm{L}\right)$ 
Table 1 Main clinical characteristics of patient

\begin{tabular}{|c|c|}
\hline \multicolumn{2}{|l|}{ Clinical characteristics } \\
\hline Diagnosis at admission & $\begin{array}{l}\text { avian influenza A(H7N9),ARDS,Sepsis,Septic } \\
\text { shock }\end{array}$ \\
\hline $\begin{array}{l}\text { H7N9-RNA } \\
\text { (BLF\&pharynx swab) }\end{array}$ & From March 13th to March 29th:positive \\
\hline Acinetobacter Baumannii & From March 17 to March 25:positive \\
\hline \multirow{3}{*}{$\begin{array}{l}\text { Respiratory support } \\
\text { (outer court) }\end{array}$} & Time from symptoms onset to NIV (15 days); \\
\hline & Time from NIV to MV initiation (1 day); \\
\hline & $\begin{array}{l}\text { Time from MV initiation to W-ECMO } \\
\text { initiation ( } 2 \text { days) }\end{array}$ \\
\hline \multirow{6}{*}{$\begin{array}{l}\text { Respiratory support } \\
\text { (our hospital) }\end{array}$} & March 13 to $19:$ W-ECMO duration \\
\hline & March 13 to April 6:MV \\
\hline & $\begin{array}{l}\text { April } 6 \text { to 9:high flow oxygen through } \\
\text { trachea cannula,oxygen flow rate:50 } 55 \\
\text { L/min }\end{array}$ \\
\hline & $\begin{array}{l}\text { April } 9 \text { to 14:high flow oxygen through } \\
\text { face mask,oxygen flow rate:35 } \sim 40 \mathrm{~L} / \mathrm{min}\end{array}$ \\
\hline & $\begin{array}{l}\text { April } 14 \text { to } 17 \text { :administering oxygen } \\
\text { inhalation through nasal catheter,oxygen } \\
\text { flow rate: } 2-6 \mathrm{~L} / \mathrm{min}\end{array}$ \\
\hline & April 17 to 20:stop oxygen inhalation \\
\hline Antiviral therapy & March 13 to April 1:Oseltamivir 150 mg,Bid \\
\hline Anti infection treatments & $\begin{array}{l}\text { March } 13 \text { to April } 16: T i e n a m ~ 1.0 \\
\text { g,Tid;Tigecycline } 50 \text { mg,Bid;Moxifloxacin } \\
400 \text { mg,Qd.etc. Adjust medication } \\
\text { according to the results of culture and } \\
\text { drug sensitivity. }\end{array}$ \\
\hline Antifungal therapy & March 13 to April 11:Micafungin 50 mg,Qd. \\
\hline steroid therapy & $\begin{array}{l}\text { March } 13 \text { to April 11:methylprednisolon } \\
80 \text { mg,Bid,gradually reduced dosage. }\end{array}$ \\
\hline
\end{tabular}

severely compromised and presents an ultimate option in problematic cases. However, indications for VVECMO are not unequivocal and it is highly invasive, presenting several specific problems and intellectual concepts that require understanding in caring for these patients. Since VV-ECMO is highly invasive and associated with numerous potential complications, such as hemorrhage, thrombosis and infection, its use should only be considered in patients with a high probability of death with conventional treatment.

In fact, H7N9-associated ARDS carries a high mortality rate. However, the care of patients with H7N9 infection has advanced since the introduction of ECMO, with increased life quality and decreased mortality. We performed a retrospective observational analysis of our experience with ECMO support for H7N9-associated ARDS. In this report, ECMO is a crucial extracorporeal life support in the H7N9 infection patient with severe ARDS.

The features of severe H7N9 avian flu patients are viral infections, dyspnea, respiratory failure and ARDS, it final developed to multiple organ failure and life-threatening. Therefore, in addition to antiviral therapy(oseltamivir), anti- multiple bacterial infections (application of antibiotics and anti-fungal drugs), glucocorticoid (methylprednisolone) and the symptomatic treatment, the timely and effective respiratory support is particularly important in treatment of severe avian flu patients.

Our patient has entered a stage of ARDS when she was hospitalized. Since mechanical ventilation by tracheal intubation could not improve patient with hypoxia, soon organ failure must occur in brain, heart, liver, kidneys and other vital organs of high oxygen demand. Emergency VV-ECMO partial instead of lung ventilation and oxygenation rapidly improved oxygen supplement of

Table 2 Ventilator and ECMO parameters

\begin{tabular}{lllll}
\hline Variable & March 13(no ECMO) at admission & March 14 ECMO(2nd day) & March 19 ECMO(7th day) & March 21 stop ECMO(3rd day) \\
\hline vital sign & T:36.7,HR:129, BP:74/36 & T:35.8,HR:76, BP:119/81 & T:36.5,HR:77, BP:122/79 & T:36.9,HR:68, BP:132/67 \\
MV mode & SIMV & PCV-SIMV & SIMV & SIMV \\
PEEP & 18 & 8 & 12 & 18 \\
$\mathrm{FiO}_{2}$ & $100 \%$ & $40 \%$ & $60 \%$ & $70 \%$ \\
$\mathrm{f}$ & 20 & 10 & 12 & 16 \\
$\mathrm{SaO}_{2}$ & $69 \% \sim 83 \%$ & $98 \%$ & $99 \%$ & $97 \%$ \\
$\mathrm{Blood}$ Flow & - & $3.46 \mathrm{~L} / \mathrm{min}$ & $3.00 \mathrm{~L} / \mathrm{min}$ & - \\
Sweep Flow & - & $2.50 \mathrm{~L} / \mathrm{min}$ & $3.00 \mathrm{~L} / \mathrm{min}$ & - \\
$\mathrm{PH}$ & 7.274 & 7.315 & 7.440 & 7.468 \\
$\mathrm{PaO}_{2}$ & 6.92 & 13.41 & 18.00 & 27.20 \\
$\mathrm{PaCO}_{2}$ & 5.69 & 4.92 & 6.06 & 6.50
\end{tabular}

$\mathrm{T}$ temperature $\left({ }^{\circ} \mathrm{C}\right), \mathrm{HR}$ heart rate(bpm), $\mathrm{BP}$ blood pressure $(\mathrm{mmHg}), \mathrm{MV}$ mechanical ventilation, $\mathrm{SIMV}$ synchronized intermittent mandatory ventilation, $\mathrm{PCV}$ Pressure Control Ventilation,PEEP Positive End Expiratory Pressure $\left(\mathrm{cmH}_{2} \mathrm{O}\right), \mathrm{FiO}_{2}$ Fraction of inspired oxygen $(\%), \mathrm{F}$ mechanical ventilation frequency $(\mathrm{bpm}), \mathrm{SaO} \mathrm{O}_{2} \mathrm{Arterial}$ Oxygen Saturation(\%,NV $>95 \%), \mathrm{PH}$ value(7.35-7.45), $\mathrm{PaO}_{2}$ Partial pressure of oxygen in arterial blood $(\mathrm{kPa}, \mathrm{NV}: 10.66-13.33), \mathrm{PaCO}{ }_{2}$ Partial pressure of carbon dioxide in arterial blood ( $\mathrm{PPa}, \mathrm{NV}: 4.65-5.98)$ 
the body organs. It avoided the occurrence of multiple organ failure, decreased support of respiratory machine, reduced ventilator-associated lung injury, for lungs to get adequate rest, thus won time for treatment of the primary disease.

Evidence supporting ECMO as life saving treatment for adults with respiratory failure are growing [10]. However, ECMO is a costly intervention that may carry the risk of futility and serious side effects such as major bleeding and infection. During ECMO support, as heparin must be applied at the same time, so thrombocytopenia and coagulopathy inevitably arise in patients. ECMO was started at 13:20 on March 13 for our patient, dramatic decrease in platelets (PLT $48 \times 10^{9} / \mathrm{L}$ ) was found on March 15. Skin ecchymosis was appeared in the groin where catheters were placed on March 19, subcutaneous hemorrhage occurred in fingers and left thigh of the patient, platelet had fallen to $21 \times 10^{9} / \mathrm{L}$. But more worrying was that bloody liquid was sucked out from bronchi and platelet transfusion did not work. Through discussion with experts, ECMO was withdrawn at 17:05 on March 19, and thrombopoietic treatment and platelet monitoring were continued, finally, the platelet returned to the normal range on April 3. Infection is another side effect of the application of ECMO. Four days after hospitalization, BLF, sputum and blood stream infection with multidrug-resistant Acinetobacter Baumannii occurred in our patient, which could lead to septic shock and death. Fortunately, we discovered and prevented the progress of infection in time.

Under these circumstances, indication and selection criteria need to be better defined.In our report, ECMO was used in severe, life threatening respiratory failure caused by a curable bird flu disease. Extracorporeal Life Support Organization (ELSO) guide-lines suggest ECMO when the risk for mortality is at least $50 \%$ (as identified by $\mathrm{PaO} 2 /$ $\mathrm{FiO} 2<150$ and or Murray score of 2-3) [11]. In this case, VV-ECMO was performed because $\mathrm{PaO} 2 / \mathrm{FiO} 2$ ratio of the patient was only $46 \mathrm{mmHg}$. Fact proved that VVECMO for $\mathrm{H7N}$ 9-associated respiratory failure gave a good result.

\section{Conclusions}

ECMO was a feasible salvage modality in this H7N9 patient with an fatal respiratory failure.ECMO is not the only factor to improve the condition of patient, the combined effect of hormone and antiviral therapy, antishock therapy helps patient to survive. It was also important to discover in time and rapid response serious ECMO-associated complications. Our patient was cured and went back to her previous quality of life at last, thanks to ECMO giving her time to get treatment. This case suggests that a multidisciplinary team, involving critical care and infectious diseases experts, is very critical to define whether ECMO is an adequate therapeutic option also in patients with severe pulmonary infectious diseases. We recommend treatment with ECMO as early as possible, but more clinical evidence is required to support this view. Further studies are needed to understand how to best utilize and optimize ECMO therapy in patients with ARDS. In short, our successful treatment of patients with severe H7N9 avian flu should be credited to application of ECMO and important ventilation adjustment according to patient's condition. Retrospective analysis of comprehensive treatment of this patient provided a reliable reference to treatment of ARDS and severe pneumonia.

\section{Abbreviations \\ ARDS: Acute respiratory distress syndrome; BLF: Bronchial lavage fluid; CT: Computed tomography; ECMO: Extracorporeal membrane oxygenation; ICU: Intensive care unit; MV: Mechanical ventilation; NIV: Non-invasive mechanical ventilation; W-ECMO: veno-venous ECMO}

\section{Acknowledgements \\ We thank all staff of Wuhan Medical Treatment Center that took part in the treatment of the patient, presented in this case report. \\ The source of funding of each author including manuscript preparation and language editing is personal budget.}

\section{Funding}

There was no involvement by the funding bodies.

Availability of data and materials

All data are fully available without restriction.

\section{Authors' contributions}

QN, D-yZ and C-IH contributed to study design, data collection, drafting and writing the manuscript, including revision. W-jW and Z-yN contributed to study design, supervision and critical revision of the manuscript for intellectual content. All authors read and approved the final manuscript.

\section{Competing interests}

The authors declare that they have no competing interests.

\section{Consent for publication}

Permission has been granted for publication of this case from the patient, a signed consent form is available to the Editors on request.

\section{Ethics approval and consent to participate}

The collection of data was approved by the local Ethical Committee regarding the use and collection of patient data within the ECMO support program. Written informed consent was obtained from the patient for publication of this Case report and any accompanying images.

Received: 9 August 2016 Accepted: 7 February 2017

Published online: 14 February 2017

\section{References}

1. The Acute Respiratory Distress Syndrome Network. Ventilation with lower tidal volumes as compared with traditional tidal volumes for acute lung injury and the acute respiratory distress syndrome. N Engl J Med. 2000;342: $1301-8$

2. Costa EL, Amato MB. The new definition for acute lung injury and acute respiratory distress syndrome:is there room for improvement? Curr Opin Crit Care. 2013;19(1):16-23.

3. Noah MA, Peek GJ, Finney SJ, Griffiths MJ, Harrison DA, Grieve R, Sadique MZ, Sekhon JS, McAuley DF, Firmin RK, Harvey C, Cordingley JJ, Price S, Vuylsteke A, Jenkins DP, Noble DW, Bloomfield R, Walsh TS, Perkins GD, Menon D, Taylor BL, Rowan KM. Referral to an extracorporeal membrane oxygenation center and mortality among patients with severe 2009 influenza A(H1N1). JAMA. 2011;306:1659-68. 
4. Bartlett RH, Roloff DW, Cornell RG, Andrews AF, Dillon PW, Zwischenberger JB. Extracorporeal circulation in neonatal respiratory failure: a prospective randomized study. Pediatrics. 1985;4:479-87.

5. Peek GJ, Moore HM, Moore N, Sosnowski AW, Firmin RK. Extracorporeal membrane oxygenation for adult respiratory failure. Chest. 1997;112:759-64.

6. Patroniti N, Zangrillo A, Pappalardo F, Peris A, Cianchi G, Braschi A, lotti GA, Arcadipane A, Panarello G, Ranieri VM, Terragni P, Antonelli M, Gattinoni L, Oleari F, Pesenti A. The Italian ECMO network experience during the 2009 influenza $A(\mathrm{H} 1 \mathrm{~N} 1)$ pandemic: preparation for severe respiratory emergency outbreaks. Intensive Care Med. 2011;37:1447-57.

7. Gattinoni L, Carleso E, Langer T. Clinical review:extracorporreal membrance oxygenation[J]. Crit Care. 2011;15(6):243.

8. Ranieri VM, Rubenfeld GD, Thompson BT, Ferguson ND, Caldwell E, Fan E, Camporota L, Slutsky AS. ARDS Definition Task Force: Acute respiratory distress syndrome: the Berlin definition. JAMA. 2012;307:2526-33.

9. Slutsky AS, Ranieri VM. Ventilator-induced lung injury. N Engl J of Med. 2013; 369:2126-36.

10. Pham T, Combes A, Rozé H, Chevret $S$, Mercat A, Roch A, Mourvillier B, AraSomohano C, Bastien O, Zogheib E, Clavel M, Constan A, Marie Richard JC, Brun-Buisson C, Brochard L. REVA Research Network: Extracorporeal membrane oxygenation for pandemic influenza $A(H 1 N 1)$ induced acute respiratory distress syndrome: a cohort study and propensity-matched analysis. Am J Respir Crit Care Med. 2013;187:276-85.

11. Paden ML, Conrad SA, Rycus PT, Thiagarajan RR. ELSO Registry: Extracorporeal life support organization registry report 2012. ASAJO. 2013;59:202-10.

\section{Submit your next manuscript to BioMed Central and we will help you at every step:}

- We accept pre-submission inquiries

- Our selector tool helps you to find the most relevant journal

- We provide round the clock customer support

- Convenient online submission

- Thorough peer review

- Inclusion in PubMed and all major indexing services

- Maximum visibility for your research

Submit your manuscript at www.biomedcentral.com/submit

) Biomed Central 